\section{IJßER}

ISSN: 2149-5939
International Journal of Social Sciences and Education Research

Online, http://dergipark.gov.tr/ijsser

Volume: 3(1), 2017

\title{
Trainees' perceptions of video use in English language teaching: Digital natives' turn
}

\author{
Ayşegül Zıngır Gülten ${ }^{1}$
}

\begin{abstract}
Received Date: 01 / 09 / 2016
Accepted Date: 24 / 12 / 2016

Abstract

The use of video in foreign language learning is known to support learning process in many different ways. Being rich and valuable resources, videos have many benefits such as providing authentic language input, bringing real world into the classroom setting, contextualizing language, grabbing students' attention, focusing students' concentration, generating interest, increasing motivation, enhancing comprehension, introducing target culture, and fostering learning. Yet, despite the widely accepted benefits of videos in Foreign Language Teaching (FLT), even in today's English Language Teaching (ELT) classrooms, learners are not exposed to such materials often. It is found out that English language teachers are either hesitant or unable to use video for language teaching purposes in classes. Triggering by this fact, the present study aims at identifying English Language Teaching (ELT) teacher trainees' perceptions of video use in ELT classrooms. Basing on the qualitative data gathered from 135 second year ELT teacher trainees, trainees' preliminary concerns of video use are sorted out. It is revealed that actually ELT trainees have positive attitudes towards video implementation. Furthermore, possible advantages and disadvantages of using video are categorized and ELT teacher trainees' suggestions on how to integrate video to our EFL situations are sorted out.
\end{abstract}

Keywords: Videos, using videos in ELT, video use and language teaching, videos and Language learning

\section{Introduction}

The use of video in language teaching dates back to 1970s. Since then, the power of videos has been realised gradually. Particularly with the effect of video technology's becoming more accessible, video use has recently gained wider recognition in foreign language teaching. Video is a rich and a valuable resource and supports language learning process in many ways. Videos provide authentic language input, bring real world into the classroom setting, contextualize language, grab students' attention, focus students' concentration, generate interest, increase motivation, enhance comprehension, introduce target culture, and foster learning (Berk, 2009; CsajbokTwerefou, 2010; Çakır, 2006; Demirezen, 1989; Lee and Liang, 2012; Stewart, 2006; Wang, 2015; Woottipong 2014). However; educational research has pointed out that despite the reported benefits of videos, foreign language learners are not exposed to such materials often (Çelik \& Aytın, 2014; Kazanoğlu, Atan \& Özçelebi, 2015; Yaratan \& Kural, 2010)

When we have a look at today's classrooms, we may easily identify how students have changed radically. Today's students are no longer the people of our educational system. They are so sophisticated with technology that they are branded as "digital natives" (Prensky, 2001:1). They are «native speakers» of the digital language of computers, video games, and the Internet. They've spent their entire lives surrounded by and using computers, video games, digital music players, video cams, cell phones and other toys.... It is now the digital natives' turn. They have

${ }^{1}$ Dr., Uludağ University, Bursa, Turkey, zingir@uludag.edu.tr 
Zingır Gülten, A. (2017). Trainees' perceptions of video use in English language teaching: Digital natives' turn.. International Journal of Social Sciences and Education Research, 3(1), 250-254.

started teaching. Thus, the purpose the present study is to identify English Language Teaching (ELT) teacher trainees' perceptions of video use in ELT classrooms.

\section{Methodology}

\subsection{Participants}

The participants of the present study are 135 second year ELT teacher trainees enrolled at Uludağ University, Bursa, Turkey. Besides skill based courses, trainees are already familiar with content based courses such as Approaches and Methods in ELT, Language Acquisition, Teaching Technologies and Materials Design and ELT Methodology courses.

\section{2. Data collection and analysis}

A questionnaire consisting of open-ended questions is developed and implemented in 2015/2016 Academic Year Spring Term. Depending on the data, teacher trainees' perceptions of video use in ELT and their suggestions are analysed qualitatively in terms of common patterns and categories.

\section{Results and discussion}

First of all, ELT teacher trainees are asked about their attitudes towards using videos in English language teaching. The data analysis reveals that; in fact, all the teacher trainees have positive attitudes towards using videos in language learning/teaching situations. Trainees indicate that videos should be used for language teaching purposes and they focus particularly on the following reasons: Videos help increasing student-motivation, focus students' attention on the lesson, keep lessons interesting, provide variety, familiarize students with the target culture, bring real world into the classroom setting, improve listening skill, help students learn better, address students with different characteristics, contextualise language, stimulate student autonomy and they are also authentic, effective, enjoyable, memorable and good pronunciation practice. When they are asked what they think about integrating videos in English language teaching, one of the trainees says:

"It's really good, since it can give students a lot of examples on how to pronounce words, gesture and mimics and it also gives students the experience of language directly from the speaker. It can also make the learning process more interesting”.

Similarly, another teacher trainee responds the same question by saying:

"Using videos provides the learner a good stimulus in the lesson. It helps the learner learn vocabulary easily. It develops students' listening skill and pronunciation. By the use of videos we can provide learners with visual and audio input. Videos make the lesson interesting. Videos improve speaking skill”.

Another trainee considers video use as a good remedy for better language learning by saying:

"Integrating films in ELT is highly beneficial for effective learning. In my opinion, they enhance the effectiveness of a lesson and draw students' attention. They can also motivate the class. Real world situations will be in class and that will make students feel closer to the subject. In the end, clear understanding and acquisition will be managed. The more usage of films in ELT, the better learning". 
Zingir Gülten, A. (2017). Trainees' perceptions of video use in English language teaching: Digital natives' turn. International Journal of Social Sciences and Education Research, 3(1), 250-254.

With regard to possible challenges and frustrations teachers may face with in video-based sessions, trainees list the followings: Cost, teachers' fear of technology, problems with sound and vision quality, maintenance, teachers' being less trained on how to use video, selecting suitable materials, classroom management problems, unexpected technological problems, the long time spent in class, and required preparation before the class. In the following quotation, some common disadvantages of video use are mentioned as follows:

"One of the disadvantages of using video is its being expensive in some specific situations which means that it costs too much. And also it could be hard to find videos about every specific subject. Teachers' lack of knowledge about instruction media such as projector, $P C$ etc. is another disadvantage. Some videos do not improve every language skill such as writing and reading".

"In general, video use has many advantages but yet there are some disadvantages as well. Firstly, with using it only with the guidance of the teacher, the classes can be too teachercentred. Students stay as passive recipients. They are technology-based so they can't guarantee things. Lack of facilities can interrupt the lesson".

Furthermore, some other teacher trainees mention about the potential limitation of video-based classes. Since such lessons usually do not have well-established methodologies and language teachers do not keep clear goals in mind, most of the time video-based courses are regarded as monotonous and ineffective. The following extracts exemplify trainees hesitations towards such video-based lessons:

"All students may not understand and get bored. Even scared of English. Maybe students think wrongly that the lesson is going to be free. And the teachers may get trouble to manage the class".

"I think, students don't take videos seriously and just have fun or enjoy them...."

"Students may focus more on the images rather than topic, students may enjoy more rather than answering the questions..."

In order to overcome the potential threats, trainees point out the importance of being well prepared for the lesson and having a contingency plan as expressed in the following lines:

"Using videos require good preparation before the lesson. Teachers need to be good organizers to use videos. They need to know when to pause and start the videos. They need a little bit technological knowledge to use them. When we use technology, we have to have a back up plan in case there should be a problem".

Trainees are also asked about their suggestions on how to integrate videos in ELT in effective ways. A great majority of the suggestions focus particularly on the following points: Choosing appropriate materials to students' level and interest, preparing activities to support video-based teaching, applying the stages: pre-/while-/post viewing effectively, giving clear purposes to students before they watch, training teachers on how to use video, being well prepared, and relying on students' creative skills. Some other trainees recommended that English teachers should work collaboratively in order to design successful video-based lessons. Samples of trainees' tips for effective video-based lessons are expressed in the quotations below: 
Zingır Gülten, A. (2017). Trainees' perceptions of video use in English language teaching: Digital natives' turn.. International Journal of Social Sciences and Education Research, 3(1), 250-254.

"If video is too long, students can get bored, distracted. Videos should be appropriate to learners ' proficiency level. If it doesn't, students can have difficulties in understanding. This affects both the students and the lesson negatively'.

"Teachers should get some information about this topic from Internet Web-sites or any other places. They should use videos with students; they should not just turn on the video and say "let's watch". They sometimes should pause the video and ask questions. They should integrate learners, too".

\section{Conclusion}

The study reveals that second year ELT trainees have positive attitudes towards video implementation and support the idea that videos should be integrated to language teaching. Knowing that the participants of the study are "digital natives", we may expect them to be more motivated to use video in their own teaching. However, as teacher trainees well indicate that video-based lessons' have potential threats like lacking well-established methodologies and clear goals, as teacher trainers it should be our concern to integrate video-based lesson planning in our curriculum. Either in our content-based courses or in the form of elective courses offered to teacher trainees, we should provide them both the necessary theoretical information and practice opportunities. By including samples of effective video-based sessions during training, we may let them realise how videos are well integrated to our daily plans.

However, these are just the initial views- trainees' perceptions only. We do not know exactly what they will do when they be actual English teachers in their own classrooms. So, further longitudinal studies might be suggested with these trainees as a follow up. Furthermore, since the present study is limited with teacher trainees' perceptions, another study might focus on practitioners views. It may also be recommended to learn more about foreign language learners' views towards video use in English lessons. Finally, collecting quantitative data or using other data collection techniques might also increase the validity and realiability of the subsequent studies.

\section{References}

Berk, R. A. (2009). Multimedia Teaching with Video Clips: TV, Movies, YouTube, and mtvU in the College Classroom. International Journal of Technology in Teaching and Learning, 5(1), 1-21.

Csajbok-Twerefou, I. (2010). The Role of Films in the Teaching of Foreign Languages. Legon Journal of the Humanities, 21, 51-75.

Çakır, İ. (2006). The Use of Video as an Audio-Visual Material in Foreign Language Teaching Classroom. The Turkish Online Journal of Educational Technology-TOJET,5, 4, Article 9.

Çelik, S. \&Aytın, K. (2014). Teachers' Views on Digital Educational Tools in English Language Learning: Benefits and Challenges in the Turkish Context. The Electronic Journal for English as a Second Language, 18, 2, 1-18.

Demirezen, M. (1990). Video Kullanımının Yabancı Dil Öğretimine Getirdikleri. Hacettepe Üniversitesi Eğitim Fakültesi Dergisi,5, 289-297.

Kazanoğlu, F., Atan, N. \&Özçelebi, H. (2015). "Yabancı Dil Öğretiminde Belgesel Film Kullanımının Öğretmen Adaylarının Dil Yetisi ve Değer Eğitimi Gelişimine Katkısı” Başlıklı Projenin Tanıtımı ve Proje Kapsamında Fransız Dili Eğitimi Anabilim Dalı Uygulamaları. Uludağ Üniversitesi Eğitim Fakültesi Dergisi, 28, 1, 371-383.

Lee, Y. J. \&Liang, J. (2012). Using Video Technology to Diagnose EFL Students' Cognitive Learning Difficulties in Public Speaking. Procedia-Social and Behavioral Sciences, 64, 671-680. 
Zingır Gülten, A. (2017). Trainees' perceptions of video use in English language teaching: Digital natives' turn. International Journal of Social Sciences and Education Research, 3(1), 250-254.

Prensky, M. (2001). Digital Natives, Digital Immigrants, Part II: Do They Really Think Differently. On the Horizon, 9, 6.

Stewart, D. M. (2006). Film English: Using Films to Teach English. Electronic Journal of English Education, 24.

Yaratan, H. \& Kural, C. (2010). Middle School English Language Teachers' Perceptions of Instructional Technology Implementation in North Cyprus. The Turkish Online Journal of Educational TechnologyTOJET, 9, 2, 161-174.

Wang, Z. (2015). An Analysis on the Use of Video Materials in College English Teaching in China. International Journal of English Language Teaching, 2, 1, 23-29.

Woottipong, K. (2014). Effect of Video Materials in the Teaching of Listening Skills for University Students. International Journal of Linguistics, 6, 4, 200-212. 